\title{
Talent Management and Organizational Performance: An Empirical Study in Retail Sector in Sylhet City, Bangladesh
}

\author{
Anwar Ahmad Arif ${ }^{1}$ Md. Reaz Uddin ${ }^{2}$ \\ ${ }^{1}$ (Department of Business Administration, Leading University, Bangladesh) \\ 2(Business Administration Discipline, Khulna University, Bangladesh)
}

\begin{abstract}
This study aims to investigate relationship between talent management and organization performance in Sylhet city, Bangladesh. Data have been collected form the employees of retail stores located in Sylhet city using structured close ended questionnaire adapting convenience sampling technique. Correlation was applied to investigate the relationship. The results show the components of talent management such as employee attraction, selection, engagement and retention have positive relationship with the performance of retail sectors in Sylhet city, Bangladesh. Employee development is identified negatively related with retail sector performance.
\end{abstract}

Keywords: Talent management, organization performance.

\section{Introduction}

Business firms tend to improve performances through generation and implementation of various policies, strategies and actions. Performance is the indicators of efficiency, effectiveness, and financial viability which are influenced by the forces of external environment (Mitchell, 2002). The current business environment is global, complex, dynamic, highly competitive and unpredictable (Schuler, Jackson \& Tarique, 2011). In this situation, human resource practitioners and consultants (HR professionals) have reiterated the importance of human capital to cope with the environmental uncertainty (ibid). Talent Management is a concept concerned with sourcing, screening, selection, retention, development, deployment, renewal of workforce in organization (Iles, Chuai, \&Preece, 2010) thus an effective technique of managing human capital. Many reputed and successful organizations such as Novartis, GE, Roche, Costco, Haier, IKEA, Google, Ford, Tata, Starbucks, LG, Siemens, P\&G, Huawei, DuPont, Unilever, Apple, Disney, 3M, Johnson \& Johnson, IBM, ABB, Toyota, Roche, Amazon, Ritz Carlton, and Southwest are practicing Talent Management for their sustainability and competitive advantage (Schuler, 2015). It is identified from a survey that nine out of ten life sciences executives emphasized on Talent Management as a key strategic priority (Stephens, 2010). Now we are turning to the details of Talent, Talent Management and its importance.

\section{What Is Talent?}

Talent is some combination of a sharp strategic mind, leadership ability, emotional maturity, communication skills, ability to attract and inspire other talented people, entrepreneurial instincts, functional skills and the ability to deliver results. (Glenn, 2012 cites Michaels, Handfield-Jones, \& Aexlrod, 2001). A clarified definition is provided by Schuler (2015) that outlines the talented employees precisely who says that talent or talented employees seem to be based on individuals who are special, have competencies valued by the company, behaviors aligned with the company's values, are hard to find, are hard to replace, can add a great deal of value to the company, have options to leave at any time and can help shape the future strategic directions of the company.

\section{What Is Talent Management?}

Talent management appeared in business and academic arenas after publication of McKinsey's research in 1998. In this research it is claimed that the corporate America was about to be engaged in a war for senior executive talent that will remain a defining characteristic of their competitive landscape for decades to come (Glenn, 2012, p. 26). Since then organizations have started thinking about talent management.

Talent management is the systematic attraction, identification, development, engagement, retention and deployment of those individuals with high potential, who are of particular value to an organization (Davies \& Davies, 2010, p. 419).

Global talent management includes all organizational activities for the purpose of attracting, selecting, engaging, developing, and retaining the best employees in the most strategic roles (those roles necessary to achieve organizational strategic priorities) on a global scale (Scullion \& Collings, 2011, p. 7). 


\section{Importance Of Talent Management}

Human Resource Management in organizations is dedicated for managing people including their recruitment, selection, training and performance appraisal. We would like to present reasons that make the talent management vital for the future of organizations and hereby state why organizations need to think about talent management beyond the human resources management.

\section{Scarcity Of Talent:}

Organizations need people and people need organizations thus the relationship is mutual. However, organizations need some people having distinctive competencies who are known talented employees. The number of talented employees is not readily available. The scenario of talented employees is reflected in the report of Deloitte published in 2008. It says that:

Despite millions of unemployed workers, there is an acute shortage of talent: science educators to teach the next generation of chemists, health care professionals of all stripes, design engineers with deep technical and interpersonal skills, and seasoned marketers who understand the Chinese marketplace. Resumes abound, yet companies still feverishly search for the people who make the difference between 10 percent and 20 percent annual growth, or between profit and loss. Critical talent is scarce (Schuler et al., 2011 cite Athey, 2008).

So when the market is in lack of talented employees it can be hard for the organizations to find them timely.

\section{Global Expansion of Business:}

Today business firms are tending to be global. The reasons are free-market ideology, technological advances, shift of economic center of gravity from the developed to the developing countries, and opening of borders to trade, investment, and technology transfers (Govindarajan \& Gupta, 2000). If we look at the value of world trade, we can imagine the expansion of trade and business. According to UNCTAD (2008), the value of world trade was USD 89 billion in 1953 but in 2008 it reached USD 10 trillion. The growth of world trade has necessitated the searching for more talents for management of business firms tending to be global.

\section{Aging of Workforce}

According to the estimation of United Nation UNC (2002), by the year of 2050, the proportion of persons aged 60 years and older is expected to bedouble, and will account for $21 \%$ of the total global population. Organizations will be facing scarcity of employees thus they need to identify the sources of talented employees.

\section{Knowledge Based Economy}

In a knowledge based economy, it is expected from the employees that they are capable of handling complex job responsibilities working with teams and diverse networks (Thunnissen, Boselie, \&Fruytier, 2013). The pattern of work in knowledge based economy is dominated by the application of modern technology. The situation demands the need of talented employees to manage the functions with greater efficiency and effectiveness.

\section{Competitiveness}

In the current business world, competitions are intense, multifaceted, complex and widespread (Schuler et al., 2011). This competition may be based on quality product, innovations, keeping low costs, accessing new market or customers. Organizations can rely on their talented employees to respond to the continuous challenges of competition. In the above sections we have discussed Talent, Talent Management (TM) and importance of TM in organizations.

\section{Research Question}

Which relations link talent management to organization performance and what talent management practices improveperformance of retail sector in Sylhet City?

\section{Theoretical Framework}

The theoretical framework shows the variables and their relationships to predict and explain a phenomenon (Malhotra \& Das, 2010). We have identified relevant variables to explain the relationship between talent management and organization performance. Talent Management consists of five elements: attracting/recruiting, selecting, engaging, developing and retaining employees (Phillips \& Roper, 2009). 
Talent Management and Organizational Performance: An Empirical Study in Retail Sector in ...

\section{Organization Performance}

According to Lebans and Euske (2006), performance is a dynamic concept and is the indicator of financial and nonfinancial factors which help to identify on which level of objectives and results are achieved. In this study organization performance will be measured based on financial and operational performance. Financial performance includes: (1) increasing rate of sales revenue; (2) increasing rate of profit; (3) increasing rate of net asset ROI (return on investment); and (4) increasing rate of market share (Daily \& Johnson, 1997). On the other hand, operational performance includes: (1) unit cost of manufacturing; (2) quality of product performance; (3) on-time delivery performance; (4) flexibility to change volume and; (5) speed of new product introduction (Ahmad \& Schroeder, 2003).

\section{Employee Attraction/Recruitment}

Organizations need talents as they have the capability to change the current and future performance (Morton, 2004, p.6). It is expected that organizations take initiatives to attract the talents as the number of talents in the labor market is limited (Athey, 2008). Thus, attracting the talents has become a challenge as well. Employer branding can be a good ways of attracting talents toward the organization. It is a systematic way of presenting organization with the intention of making it distinctive from others for the potential and current employees. Employer branding is the sum of all efforts from the company to communicate to existing and prospective staff that it is a desirable place to work (Lloyd, 2002). Chhabra and Sharma (2014) find positive relationships between the employer brand and the likelihood of applying. The image of the organization is created by the effects of good corporate citizenship, progressive labor practices, an emphasis on diversity, sponsorship of cultural activities, and pro-environmental practices (Smith, Bauer, \& Cable, 2001). Lemmink, Schuijf and Streukens (2003) find that corporate image and company employment image have a significant effect on the intentions of applications. Sheahan (2005) comments that questionable business practices damage organizations image in the markets and create negative, consequences thus it is unlikely that talented people will show their interest. An organization's website contains information about the vision, mission, current activities and future plan that may allure the talents. The content and style of an organization's websites can enhance the organization's attractiveness which in turn affects the recruitment (Cober, Brown, Cober, Levy, \& Keeping, 2007).

Boxall and Purcell (2003) argue that firms need to attract and nurture people who have the competencies and ability that will contribute to enhance organization performance. Katou and Budhwar (2007) studying the effect of HRM policies on organization performance in Greek manufacturing firms find that the relationship between recruitment and performance is positive. Furthermore, Aposporia, Nikandroua, Brewsterb and Papalexandrisa (2008) in their study on HRM and organizational performance in northern and southern Europe have also found that the recruitment is positively related with organization performance. Aposporia et al. (2008) applied productivity and profitability to measure performance and; Katou and Budhwar (2007) used operational measures such as effectiveness, efficiency, development, quality, innovation. Performance measures of our model have similarity with measures of these studies. Based on the empirical evidences it has been concluded that employee attraction/recruitment has relationship with organization performance.

\section{Employee Selection}

As talent management has revealed more importance, the selecting activities within hiring talented employees become significant as this is where the company selects new employees - hopefully with a lot of talent. Selecting the right candidate is crucial for the organization and the candidate as no one wishes to waste time, energy and money.

Arthur (2006) states that there are several important activities to follow for selecting employees. As a hiring manager one needs to conduct interviews which are legal and based on competencies for the specific job. Background and reference checks are necessary as well as the conductions of relevant tests.

Studer (2006) believes that there are three steps for selecting talent: (1) use prescreening to select for organizational fit, (2) use behavioral-based interview to ensure job and skill set fit and (3) use peer interviews to ensure cultural fit. The first step is to ensure that the candidate is willing to support the values of the organization; hence the attitude of the candidate is important. This fit can be investigated by asking behavioralbased questions. Questions like these investigate the candidate's previous behavior in given situations. Based on the answers the hiring managers can ensure that the behavior of the candidate reflects the standard behavior of the organization. The second step refers to the activity in step one where behavioral-based questions are used. Besides understanding if the candidate fits the organization their job skills can be investigated with the same method and previous episodes are asked about. This will enhance the changes of the hiring managers to figure out whether the candidate is suitable for the job and has the proper talent, they are looking for. Often employees have to cooperate together in their job functions and this is why there is this third step. This involves having a few of the high-performing employees to engage in the selection process of new employees. Having somewhat 
of a saying also increases the success of the new hire, since they are more likely to support him or her. The final decision is of course still the hiring manager's.

Terpstra and Rozell (1993) have found significant positive relationship between staffing practices and performance in their study. In another study on hotel industry in India, Chand and Katou (2007) found the relationship between selection and organization performance positive. Furthermore, Ahmad and Schroeder (2003) in their study on the impact of human resource management on operational performance find that hiring contributes to improve organization performance. These studies have measured performance using either operational or financial measures such as Terpstra and Rozell (1993) have used annual sales growth and profits; Chand and Katou ( 2007) used sales growth, productivity, profitability, goal achievement, good services; and Ahmad and Schroeder (2003) have used both operational (quality, flexibility, innovation) and financial ( profit, sales). Performance measures of our model have similarity to the performance measures of these studies thus relevant in our case. Based on evidence of these studies it is concluded that selection is related with organization performance.

\section{Employee Engagement}

Organizations want to have engaged employees in their organization, which is more than just satisfied employees. According to Phillips and Roper (2009), if employees are engaged in their job they possess some qualities as: innovation and creativity, taking responsibility, authentic desire to make the organizational successful and having an emotional bond to the organization and its mission and vision.

Engagement of employees bears great significance for the organizations. Still there are different aspects that can be used to generalize which activities could be most proper in engaging employees in the organization. According to Konrad (2006), high involvement work systems can impact employees' engagement if the systems are effective and working together. The principles of the high involvement contain power, information, knowledge and rewards.

Power for the employees mean that they have the power to influence or decide important aspect related to their performance and the quality of their working lives. The rank of power can be from influencing and providing input to actually having the final authority and responsibility to make the decisions. If employees have the change to develop and share ideas for improving the performance in the organization, then it can be effective if good ideas are being used.

Information is an important aspect of the high involvement, since the employees must have the correct information and data to be able to perform well. Data like cost, revenue, profitability and customer reactions can be important so employees have the correct information and thereby have the ability to act according to this. The challenge of course lies within the managers' ability to share the correct information with the correct employees at the right time. This can be done with a proper information system which must be created. If employees are able to view the performance from their activities, it can contribute to the organizational performance because the employees know exactly where changes must be made.

The employees' knowledge is their ability and skill which they use to act and make decisions. Employees should be trained and developed to be able to make the right decisions for the company. Training these abilities and skill are important for the high involvement of employees hence the engagement of employees.

The last principle is rewards. Employees need to be rewarded if they are making great efforts to change the organizational performance. This rewarding is relevant and necessary to give the employees incentive to use their power, information and knowledge to help the organization in a positive way. Using these activities may help the organization engage the talented employees so they become more talented to perform their certain job and consequently higher the overall organizational performance.

A report published by Harvard Business Review Analytic Services based on a survey shows that $71 \%$ of respondents rank employee engagement as very important to achieving overall organizational success (Harvard Business Review Analytical Report, 2013). Success indicators such as productivity, quality improvement, ability to innovate, sales capability have been used in this study. Besides, Harter, Schmidt, and Hayes (2002) have found positive relations between employee engagement and business unit performance where performance measures are customer satisfaction, profit, productivity, turnover and safety. These studies are relevant for our model because of close similarity of performance measures. Furthermore, Hughes and Rog (2008) noted that employee engagement is associated with operational and financial performance of organizations. Based on the finding of the study it can be said that employee engagement has relationship with organization performance.

\section{Employee Development}

Employee development is an ongoing process of assisting employees on how to perform the work. It is one of the significant functions of Human Resource Management as employees are critical to an organizations 
success (Ferris, Hochwarter, Buckley, Harrell-Cook \& Frink, 1999).Employee development is an integrated set of planned programs designed to assure that all individuals have the competence necessary to perform to their fullest potential in support of the organization's goal (Jacobs \& Washington, 2003). A successful employee development results from the balance between individual's career orientation and needs, and the organization's mission and vision (Shelton, 2001). Employee development activities include off-the-job and on-the-job training programs, educational programs and seminars, job rotations, self-study materials and mentoring programs (Jacobs \& Washington, 2003). These programs facilitate improvement of employee capabilities needed for carrying out daily functions of organizations. Employee development activities are important particularly for new employees who enter the organization (Holton, 1996) to build the capabilities appropriate for the workplace.

Torraco and Swanson (1995) state that employee development offers various leaning opportunities to perform their jobs better which in turn enable the organization as a whole to enhance performance. Empirical studies such as Ngo, Turban, Lau and Lui (1998); Chand andKatou(2007) have found training \& development is positively related with organization performance. Chand and Katou (2007) used sales growth, productivity, profitability, goal achievement, good services; and Ngo et al. (19980) used sales, net profit, and development of new product/services to measure performance in their studies. Performance measures of our model have similarity with the performance measures of these studies. Although in our model the construct is Employee Development but in these studies the construct is named Training \& Development but the focus is same that is enhancing employee capability. Based on the empirical evidence it has been concluded that employee development has relationship with organization performance

\section{Employee Retention}

Employee retention is the systematic technique applied by the management to help employee stay for a longer period of time (Tephillah \& Swamalatha, 2015). Organizations tend formulate suitable human resource policies and strategies to attract and keep employment of the best available talents (Shekshnia, 1994).

Irshad (2007) has identified some important HR practices that can influence the retention of employees in the organization. First, organization culture plays a crucial role in retaining employees in the organization. Second, family and flexible time option can also be considered as the important factor for employee retention. Third, compensation and recognition are considered as motivation to employees which leads to their retention in the firm. Fourth, career development and promotion opportunities drive retention.

Retaining talent employees is a primary concern for many organizations because of their knowledge and ability needed to enhance financial and operational performance (Hausknecht, Rodda, \& Howard, 2009). Hughes and Rog (2008) in their work on hospitality organization noted that improved retention rates are associated with operational and financial performance of organizations. Kontoghiorghes and Frangou (2009) have found that talent retention is positively correlated with organization performance. This study measured performance using quality, productivity, response to environment, innovation, customer value, adaptation. Operational performance measures of our model have similarity with the performance measures used by the study. Based on the empirical evidence it is concluded that employee retention is related with organization performance.

\section{Methodology}

In this study, the intention is to identify the relationship between Talent Management (TM) and organizational performance in retail sector. Quantitative methodology is appropriate for investigating relations between variables in social science (Bryman, 1984). Data have been collected from the employees of Retail Stores in Sylhet City, Bangladesh using structured closed ended questionnaire through survey to capture their opinions. Convenience sampling technique has been applied to collect opinions from employees. A total 100 employees from the retail stores in Sylhet city were interviewed with structured questionnaire. Questionnaire has been developed operationalizing elements of Talent Management such as employee attraction, selection, engagement, development, and retention; and organization performance separately. A five point Likert type scale has been used to measure the opinions. Correlations techniques have been applied to investigate the relationship between organization performance and Talent Management. The results show the nature of relationship between Talent Management and organization performance.

\section{Data Analysis and Interpretation}

It reveals from the analysis that organization performance has relationship with employee attraction, selection, engagement, development and retention. The nature of relation is positive except employee development which is negatively related with the retail sector performance in Sylhet City, Bangladesh. The relationship between retail sector performance and employee retention is statistically significant $(p<.05)$. 
Talent Management and Organizational Performance: An Empirical Study in Retail Sector in ...

Employee attraction, selection, engagement, and retention are positively related with retail sector performance in Bangladesh. It signifies that improved attraction, selection, engagement and retention activities are expected to enhance the performance of the retail sector.

\section{Correlations}

\begin{tabular}{|c|c|c|c|c|c|c|c|}
\hline & & Performance & Attraction & Selection & Engagement & Development & Retention \\
\hline \multirow[t]{2}{*}{ Performance } & $\begin{array}{l}\text { Pearson } \\
\text { Correlation }\end{array}$ & 1 & .190 & .084 & .071 & -.030 & $.209(*)$ \\
\hline & Sig. (2-tailed) & & .058 & .404 & .480 & .771 & .037 \\
\hline \multirow[t]{2}{*}{ Attraction } & $\begin{array}{l}\text { Pearson } \\
\text { Correlation }\end{array}$ & & 1 & $.505(* *)$ & $.351(* *)$ & .167 & .183 \\
\hline & Sig. (2-tailed) & & & .000 & .000 & .097 & .068 \\
\hline \multirow[t]{3}{*}{ Selection } & $\begin{array}{l}\text { Pearson } \\
\text { Correlation }\end{array}$ & & & 1 & $.324(* *)$ & .191 & -.004 \\
\hline & Sig. (2-tailed) & & & & .001 & .056 & .967 \\
\hline & $\mathrm{N}$ & & & & 100 & 100 & 100 \\
\hline Engagement & $\begin{array}{l}\text { Pearson } \\
\text { Correlation }\end{array}$ & & & & 1 & .127 & .179 \\
\hline \multirow{2}{*}{ Development } & Sig. (2-tailed) & & & & & & .470 \\
\hline & $\mathrm{N}$ & & & & & & 100 \\
\hline \multirow[t]{3}{*}{ Retention } & $\begin{array}{l}\text { Pearson } \\
\text { Correlation }\end{array}$ & & & & & & 1 \\
\hline & Sig. (2-tailed) & & & & & & \\
\hline & $\mathrm{N}$ & & & & & & \\
\hline
\end{tabular}

* Correlation is significant at the 0.05 level (2-tailed).

** Correlation is significant at the 0.01 level (2-tailed).

\section{Discussion and Conclusion}

This study has been designed to investigate relationship between talent management and retail sector performance in Bangladesh. The components of talent management (employee attraction, selection, engagement, development and retention) have positive relations with retail sector performance except employee development which reveals negatively related. The positive relationships between retail sector performance and employee attraction, selection, engagement and retention are consistent with previous research conducted to investigate such relations (Aposporia et al., 2008; Terpstra and Rozell, 1993; Chand and Katou, 2007; Hughes and Rog, 2008; Kontoghiorghes and Frangou, 2009). Although pervious research found positive relations between employee development and organization performance (Torraco and Swanson, 1995) but the finding of this study in this regard is not line with previous result.

The findings of this study have implications for the retail sectors in Sylhet City, Bangladesh. It is true that business firms tend to improve their performances thus they seek for the ways for improving performance. They get the ways from this study to improve their organization performance. The study shows that retail sector needs to pay attention on employee attraction, selection, engagement and retention for improvement of performance.

This study has been conducted collecting data from the retail stores operated in Sylhet city only. The findings may not represent a complete scenario of Bangladesh retail sector hence the results should be considered subject to this limitation. Future research may be designed targeting the whole retail sector in Bangladesh to get a conclusive scenario regarding the relationship between talent management and organization performance.

Existing literature on Talent Management has focused on the conceptualization of talent and talent management; talent management activities and practices; the intended outcomes and effect of talent management (Thunnissen et al., 2013). This study developed a theoretical model which states the relationships talent management and organizational performance. This model has been tested empirically collecting data from the employees of retail sector to find out relationship talent management and organization performance. This study is an important contribution in talent management literature since there are a limited number of empirical researches on talent management (Thunnissen et al.,2013). 


\section{References}

[1]. Ahmad, S., \& Schroeder, R.G. (2003). The impact of human resource management practices on operational performance: Recognizing country and industry differences. Journal of Operations Management,21(1), 19-43.

[2]. Apospori, E., Nikandrou, I., Brewster, C., \&Papalexandris, N. (2008).HRM and organizational performance in northern and southern Europe. The International Journal of Human Resource Management, 19(7), 1187-1207.

[3]. Arthur, D. (2006). Recruiting, Interviewing, Selecting \& Orienting New Employees. American Management Association (Pub), New York.

[4]. Athey, R. (2008). It's 2008: Do You Know Where Your Talent Is? Why Acquisition And Retention Strategies Don't Work. A Deloitte Research Study, Deloitte Development LLC.

[5]. Boxall, P., \& Purcell, J. (2003).Strategy and human resource management. Basingstoke, UK: Palgrave Macmillan.

[6]. Bryman, A. (1984). The debate about quantitative and qualitative research: A question of method or epistemology. British Journal of Sociology, 35(1), 75-92.

[7]. Chand, M., \&Katou, A.A. (2007). The impact of HRM practices on organizational performance in the Indian hotel industry. Employee Relations, 29 (6), 576-594

[8]. Chhabra, N.L., \& Sharma, S. (2014). Employee branding: Strategy for improving employer attraction. International Journal of Organizational Analysis, 22 (1), 48-60.

[9]. Cober, R. T., Brown, D. J., Levy, P. E., Cober, A. B., \& Keeping, L. M. (2003). Organizational web sites: Web site content and style as determinants of organizational attraction. International Journal of Selection and Assessment, 11(2-3), 158-169.

[10]. Daily, C.M., \& Johnson, J.L. (1997). Sources of CEO power and firm financial performance: A longitudinal assessment. Journal of Management,23 (2), 97-117.

[11]. Davies, B., \& Davies, B. J. (2010).Talent management in academies.International Journal of Educational Management, 24(5), 418426.

[12]. Ferris, G. R., Hochwarter, W. A., Buckley, M. R., Harrell-Cook, G., \& Frink, D. D. (1999). Human resources management: Some new directions. Journal of Management, 25(3), 385-415.

[13]. Glenn,G. ( 2012). The state of talent management in Canada's public sector.Canadian Public Administration, 5(1), 25-51.

[14]. Govindarajan, V., \& Gupta, A. (2000).Analysis of the emerging global arena. European Management Journal, 18(3), $274-284$.

[15]. Harter, J. K., Schmidt, F. L., \& Hayes, T. L. (2002). Business-unit-level relationship between employee satisfaction, employee engagement, and business outcomes: A meta-analysis. Journal of Applied Psychology, 87(2), 268-279.

[16]. Harvard Business Review Analytical Report (2013). The impact of employee engagement on performance. Harvard Business Review. Retrieved from: https://hbr.org/resources/pdfs/comm/achievers/hbr_achievers_report_sep13.pdf (Accessed on: 18 February 2016).

[17]. Hausknecht, J. P., Rodda, J., \& Howard, M. J. (2009). Targeted employee retention: Performance based and job related differences in reported reasons for staying. Human Resource Management, 48(2), 269-288.

[18]. Holton, E. F. (1996). New employee development: A review and reconceptualization. Human Resource Development Quarterly, 7(3), 233.

[19]. Hughes, J.C., \& Rog, E. (2008). Talent management: A strategy for improving employee recruitment, retention and engagement within hospitality organizations. International Journal of Contemporary Hospitality Management, 20 (7), 743 - 757.

[20]. Irshad, M. (2007). Factors affecting employees retentions: Evidence from literature. Abasyn Journal of Social Sciences, 4(1), 307339.

[21]. Jacobs, R., \& Washington, C. (2003). Employee development and organizational performance: a review of literature and directions for future research. Human Resource Development International, 6(3), 343-354.

[22]. Katou, A.A., \&Budhwar, P.S. (2007).The Effect of human resource management policies on organizational performance in Greek manufacturing firms.Thunderbird International Business Review, 49(1), 1-35.

[23]. Konard, M.A. (2006). Engaging employees through high-involvement work practices, Ivey Business Journal. Retrieved from http://www.jwalkonline.org/docs/Grad\%20Classes/Fall\%2007/Org\%20Develop/presentation/ARTICLES/engage\%20employ\%20hi ghinvolve\%20work\%20prac.pdf (Accessed: 23 January 23, 2016).

[24]. Kontoghiorghes, C., \&Frangou, K. (2009). The association between talent retention, antecedent factors, and consequent organizational performance.SAM Advanced Management Journal, 74(1), 29.

[25]. Lebans, M., \&Euske, K. (2006).A Conceptual and Operational Delineation of Performance, Business Performance Measurement.Cambridge University Press.

[26]. Lemmink, J., Schuijf, A., \&Streukens, S. (2003). The role of corporate image and company employment image in explaining application intentions.Journal of Economic Psychology, 24(1), 1-15.

[27]. Lloyd, S. (2002). Branding from the Inside out.Business Review Weekly, 24(10), 64-66.

[28]. Malhotra, N.K., \& Das, S. (2010). Marketing Research: An Applied Orientation.Pearson Publication. India.

[29]. Michaels, E., Handfield-Jones, H., \& Axelrod, B. (2001).The War for Talent. Boston: Harvard Business School Press.

[30]. Mitchell, H. (2002). Strategic worth of human resources: Driving organization performance. Retrieved from http://www.exinfm.com/pdffiles/stratworth.pdf_(Accessed: 23 January 2016).

[31]. Morton, L. (2004). Integrated and integrative talent management: A strategic HR framework, Research Report R-1345-04-RR, The Conference Board, New York, NY.

[32]. Ngo, H. Y., Turban, D., Lau, C. M., \&Lui, S. Y. (1998). Human resource practices and firm performance of multinational corporations: Influences of country origin. International Journal of Human Resource Management, 9(4), 632-652.

[33]. Phillips, D.R., \& Roper, K.O. (2009).A framework for talent management in real estate.Journal of Corporate Real Estate, 11(1), 716.

[34]. Schuler, R. S. (2015). The 5-C framework for managing talent. Organizational Dynamics, 1(44), 47-56.

[35]. Schuler, R. S., Jackson, S. E., \&Tarique, I. (2011). Global talent management and global talent challenges: Strategic opportunities for IHRM. Journal of World Business, 46(4), 506-516.

[36]. Scullion, H., \& Collings, D.G. (2011).Global Talent Management, London and New York: Routledge.

[37]. Sheahan, P. (2005). Generation Y: Thriving and surviving with generation Y at work. South Yarra, WA: Hardie Grant Books.

[38]. Shekshnia, S. (1994). Managing people in Russia: Challenges for foreign investors. European Management Journal,12 (3), 298305 .

[39]. Shelton, K. (2001). The effects of employee development programs on job satisfaction and employee retention. Retrieved from http://www2.uwstout.edu/content/lib/thesis/2001/2001sheltonk.pdf (Accessed: 6 January 2016).

[40]. Smith, L.A., Bauer, T.N., \& Cable, D.M. (2001). Are you attracted? Do you intend to pursue? A recruiting policy-capturing Study. Journal of Business and Psychology, 16(2), 219-237. 
[41]. Stephens, N. (2010). Talent management: ensuring your people give you the competitive edge. Strategic Direction, 26 (7), 3 - 5.

[42]. Studer, Q. (2006). Selecting and retaining talent: Tools for the bottom line, healthcare registration. Retrieved from http://web.b.ebscohost.com.proxy1-bib.sdu.dk:2048/ehost/pdfviewer/pdfviewer?sid=50a906e4-627e-4664-bb94a2abb0445b38\%40sessionmgr114\&vid=1\&hid=125 (Accessed: 23 January 2016).

[43]. Sykes, A.O. (1993). An introduction to regression analysis. Retrieved from http://chicagounbound.uchicago.edu/cgi/viewcontent.cgi?article=1050\&context=law_and_economics , (Accessed: 23 January 2016).

[44]. Tephillah, V.S., \&Swamalatha (2015).Importance of employee retention.Indian Journal of Marketing and Finance,5(8). Retrieved from: http://www.indianjournals.com/ijor.aspx?target=ijor:ijrfm\&volume=5\&issue=8\&article=002 (Accessed: 18 February 2016).

[45]. Terpstra, D. E., \&Rozell, E. J. (1993). The relationship of staffing practices to organizational level measures of performance. Personnel Psychology, 46(1), 27-48.

[46]. Thunnissen, M., Boselie, P., \&Fruytier, B. (2013). A review of talent management: Infancy or adolescence. International Journal of HRM, 24(9), 1744-1761.

[47]. Torraco, R. J., \& Swanson, R. A. (1995).The strategic roles of human resource development.HR: Human Resource Planning, 8(4), $10-21$.

[48]. UNCTAD.(2008). World investment report. Geneva: United States press release (2014). Retrieved from https://www.wto.org/english/news_e/pres14_e/pr721_e.htm (Accessed: 19 December 2015).

[49]. United Nations UNC (2002). International plan of action on ageing 2002.Second world assembly on ageing Madrid. Retrieved from http://www.un.org/en/events/pastevents/pdfs/Madrid_plan.pdf (Accessed: 22 January 2016). 